\title{
Universality of Waiting for Godot
}

\author{
Khalid J. Oudah Alogaili and Ali G. Khalaf
}

\begin{abstract}
The aim of this study is to trace the universality of Samuel Beckett's play 'Waiting For Godot'. To achieve the goals of the research, it is necessary to investigate deeply the elements involved the play transferring it from locality into universality. These elements are: First, the poetic form which basically depends on the special language of the play. Second, the universal or non-determined theme. Third, the influence of the play which is shown in others' works. Thus, all these elements combined together to make it universal. The play enjoys a remarkable reputation; this reputation comes from themes it discuses and the mysteriousness of the title. The play was translated into many languages and it is still performed in many countries all around the world.
\end{abstract}

Index Terms-Absurdity of the play, elements of universality, poetic form, universal theme.

\section{INTRODUCTION}

Beckett's theatre does not represent scenes from another time or rather it does not only do so. His theatre does create scenes that their subject matter is their duration in the present time. Beckett's plays are not about experiences, but they are experiences themselves. Though the audience was already introduced to the modern modes of theater prior Beckett's 'Waiting for Godot', the play had the most profound and wide-ranging effect on them. Before Theatre of Absurd, the audiences expected a well-made and life-like play, actual characters, acceptable language, and well-interwoven plots with beginning, middle and denouement, but this theatre devastated all these expectations. A well example of Theatre of

Absurd is Beckett's play 'Waiting for Godot' in which characters are unfamiliar and tramps, strangely motivated; the dialogue they use is bunk and nonsense. The play has no identifiable beginning, middle and an end, thus, it has no plot but a story and the way of telling this story is arbitrary. The writer does not offer any remedy to the observed troubles that the two characters face. Therefore, the play is out of the conventional dramatic circle, it is common in tradition of 'Theatre of Absurd' [1].

The 'theater of absurd' works as poetry rather than narrative. Conventional narrative play tells a story and it develops dynamically. Thus, the characters grow and change before the audience's eyes, and that is the story aims to expose the change and growth. What distinguishes 'Waiting for Godot' from all

Manuscript received December 15, 2017; revised February 20, 2018.

Khalid J. Oudah Alogaili is with the Department of English, faculty of Arts, University of Kufa, Iraq.

Ali G. Khalaf is with University of Kufa, Iraq (e-mail: alig.khalaf@uokufa.edu.iq). other plays is the absence of almost any action of any kind. It leaves the audience exactly where it finds them. The play comes to have some of the fascination of a walker on a tight-rope who keeps the audience stuck to their seats not by the distance he travels but by the fact that he is there at all [2].

\section{EXISTENTIALIST VIEW}

The influential and theoretical manifestations of existentialism occur in the works of Beckett, Ionesco and Pinter in which certainty in the supposed social and dramatic 'givens' of circumstances, personality and language are undetermined. Existence precedes essence. Though meaning is not 'out there' we can create in 'in here,' within ourselves. Existentialism is an advanced step up from nihilism, because, when the nihilist affirms meaninglessness out there and leaves it at that, the existentialist affirms meaninglessness (out there) but keeps on to affirm that it is the individual's responsibility to create meaning (in here). Of course it's more sophisticated than that, but it is a bird's eye view of their relationship [3].

The prominent concept of existentialism is; the factual existence of the individual, is the basic fact that man is not predestined by God or society, he has a free will. The two absolute truths of life are first, birth and death, second, the memories and experiences, which define what lies between these two truths are structured into a linear progression of human mind into the conception known as 'time'. So, if someone accepts this existentialist view, the conception of destiny and fate cannot be existed. Each moment of life is dictated by circumstances and chance, which bestow fortune on some, while misery on others. Beckett presents the world of Estragon and Vladimir as a world of chaos lacking meaningful structure. The world in which time is applied, where days end without any notice and the characters do not remember anything took place in the day before. Thus, time is meaningless as it experienced by an ultimate repetition of a endless waiting in sight but death. This boring process of waiting is recurrent and repetitious. However, the variations in the repletion become clear in act ii and they are remarkable in Lucky and Pozzo during their second meeting with Estragon and Vladimir. The dramatic changes occur in Pozzo and Lucky are manifestations of time and meaninglessness of life. The blind is a force of chance and circumstance, which indiscriminately wield themselves on the human race, making life and time insignificant, and the terminal individual universality(p. 50) [2].

Beckett makes birth and death as the only absolute truths within the play in order to establish time and life as insignificant receivers of random consequence. The existence 
of these men between the beginning and end of their lives is only substantiated by their interactions and relationship to each other. However, they themselves even them into this world, but what anchors their reality in life? There is no proof or tangible meaning to their lives, except for their fruitless wait for Godot. Estragon and Vladimir's individual existence and role in the world are thus dimmed due to their inseparable lives and consciousness. Their lives are so interwoven that a unique and individual perception is nearly impossible. They must depend on each other every day to remember what they did and where they did it. Their voices often ring together in one common voice during language games they play to pass the time, proclaiming the universality of their existence $(p, 78)$ [2].

'Waiting for Godot' is considered an essential expression of existentialism. The two tramps Estragon and Vladimir are waiting endlessly and pointlessly for someone unseen called 'Godot' who maybe actually existed. Existentialism is a fully a amorphous conception referring to man's nature and his relation to the world he lives. It is a new philosophical concept that analysts and critics feel they find its greatest expression in Beckett's treatment. One the pivotal belief of existentialism is the sense that life is cyclic; what happened in past will happen again. As it is, 'Waiting for Godot' presents endless examples of the two main characters speaking and repeating themselves in circles. The pattern and style of the dialogue that can make the play a completely maddening experience if the viewer doesn't happen to be in the right frame of mind, which would beg the question of why that viewer would be in the audience in first place. Godot's existence is just a part of the play, as the visitation of both Pozzo and Lucky would give Beckett a chance to inject an additional absurdity into his narrative, as when the second visit by Pozzo and Lucky evokes an increased sense of existential doubt when Pozzo disputes the idea that he has been at this precise spot on the day before claiming to have lost his sight. Then Estragon and Vladimir engage in futile discussion of whether they exist and how they know so [4].

\section{ThE ABSURDITy OF THE Play}

The word 'absurd' simply means ridiculous but this is not the sense when we talk about the Theatre of absurd. The theatre of absurd struggles to show the senselessness of human's condition and the fragility of the rational approach through the open abandonment of rational devices and digressive thought. It also tends towards a radical depreciation of language, towards the poetry that is emerged from the concrete and objectified images of the stage itself. The language element still plays an eminent part in this conception, but what happens on the stage transcends and often contradicts the words spoken by the characters. The theatre of the absurd is a part of 'anti-literary' movement of the time, which has found its expression in abstract painting with its rejection of 'literary' elements in pictures. It is not true to say that the theatre of absurd is basically French, because it is based on the coast of western convention and its fundamentals were found in Britain, Italy, Spain, Switzerland and America as well as France. Moreover, the pioneers of the theatre who lived in France and wrote in French were not French writers. Though the favourable circumstances deeply rooted in the fruitful culture of Paris climate, the successfulness of the theatre of absurd was achieved within a short scope of time and remained one of the most stunning aspects of this astonishing phenomenon. However, The plays belong to the theatre of absurd are puzzling and so strange. They are empty from traditional attractions of well made plays and in spite of this they were performed on most of world stages: from Finland to Japan, from Argentina to Norway. They themselves powerful and fully empirical tests of the theatre of absurd significance (p. 16-20) [2].

Both the French title En Attendant Godot and English Waiting for Godot express what is meant in a rich sense: a state of suspension and readiness in which one will attend to the arrival of an awaited object. This waiting is a fundamentally conservative activity that searches the restoration of something or someone whose absence is profoundly felt, even if the lost object has never actually been present. The act of waiting maybe also considered a kind of worship and an expression of disinheritance. However, as Vladimir and Estragon wait, their lives become hopeless, helpless, meaningless and absurd. Although, Godot will not attend and his coming has no significance, they still wait [5].

The main subject of the play "Waiting for Godot" is waiting. The dialogue is anticipatory, nonlinear and timeless. It has no resolution: at the end of the first act, Estragon said 'well shall we go?' the respond by his friend Vladimir was 'yes, let's go'. But they did not move, and then the curtain dropped. At the end of the second act, the same thing happened but the roles were changed i.e. Vladimir asked ' well? Shall we go?' and Estragon answered 'yes, let's go'. Once more they did not move until the curtain dropped. Thus, the dialogue of the characters is full with a tone of futility:

Estragon: What'll we do, what'll we do!

Vladimir: There's nothing we can do.

Estragon: But I can't go on like this.

Vladimir: Would you like a radish?

Estragon: Is that all there is?

Vladimir: There are radishes and turnips [6].

Vladimir's phrase 'would you like a radish?' is neither answering Estragon's question 'what'll we do?' nor responding to the couplet: 'there's nothing we can do' and 'but I can't go on like this'. The response of a 'radish' to the existential question is one example of the absurdity of the dialogue [7].

\section{Prevalence of the Play}

Beckett's real triumph came when his play 'Waiting for Godot', which had emerged in book form in 1952, was first produced on January 5, 1953 entitled 'Theatre de Babylone' on the Boulevard Raspail. So its triumph constituted the penetration into public consciousness of a new tradition of 
drama which had been vaguely labeled with the generic term of 'Theatre of Absurd'. Out of all expectations, the strange tragic farce in which nothing happens and which had been despised as non-dramatic by a number of managements, became one of the greatest successes of the post-war theatre. It ran for four hundred performances at the 'Theatre de Babylone' and was later transferred to another Parisian theatre. It was translated into more than twenty languages and performed in Sweden, Switzerland, Finland, Italy, Norway, Denmark, Holland, Spain, Belgium, Turkey, Yugoslavia, Brazil, Mexico, Argentina, Israel, Czechoslovakia, Poland, Japan, Western Germany, Great Britain, the United States and Ireland. It was seen within the first five years after its first original production in Paris by more than million audiences [8].

Beckett's play does not conform to the requirements of any traditional play. He introduced certain things, which contributed to the theatrical success. 'Waiting for Godot' is one of the most commercially successful plays in the twentieth century. Beckett jumped into fame because of this play. It puzzled the readers and the spectators and it enabled them to exercise their intellect and emotions as well. So both the audience and the readers are free to take it on whichever level they choose. The five characters in the play are drawn from different nationalities; this gives the play a universal appeal. Since the dramatic personae are drawn from different parts of the world, the play has being translated into innumerable languages and performed all over the world. Beckett conveys that since time has no meaninglessness in this play, life is meaningless too, because both life and time are controlled by circumstances, chance and change. When Pozzo was questioned of how and why he became blind, he replied; "I woke up one day blind as Fortune". In Waiting for Godot, man's spirit rebels against the necessity of being born and the necessity of eking out the existence, so this explains why the play gained wider dimensions and even universal significance [9].

\section{UNCERTAINTY}

The pattern of uncertainty and questions, an action elucidating the absence of action, this is the essence of 'Waiting for Godot'. The title is itself puzzling; if we have a look at it attentively without any preconceived notions of what drama has to be, we will see so clearly what the Beckett wants to show: human beings waiting for the arrival of something or someone with whom there is or there is no an appointment (60) [8].

Beckett plays very skillfully on two of the commonest human experiences; uncertainty and expectancy. Uncertainty is a disturbing experience that almost every individual has in his own life, and in the second half of the twentieth century it has become a characteristic of the age. Expectancy, when it is unfulfilled, itself becomes but another form of uncertainty, and it is the transition from one to another that constitutes what leads for a need of a better term, which be called the dramatic action of 'Waiting for Godot'. The play attracts the audience by its religious uncertainty. Although personal faith has declined, people continue to be interested in religion and the Biblical overtones of Beckett's play, which suggests an area of uncertainty that is widely shared. Godot is not God but it sounds like God and there are Biblical allusions in the dialogue that give a hazily religious background to the conversation between the two tramps Estragon and Vladimir, who are alone on the stage for the greater part of the time [10].

If you genuinely believe that what normally passes for reality is actually so much fiction, the most real element in the fiction you write will be the uncertainty. For the characters in the play, this kind of uncertainty about past events, irrespective of whether they're in the remote past or the immediate past, keeps dragging them into the present. To be sure of the reality of your own existence, you need to be sure of what is happened to you. This why Vladimir and Estragon spend so much time arguing about what happened yesterday:

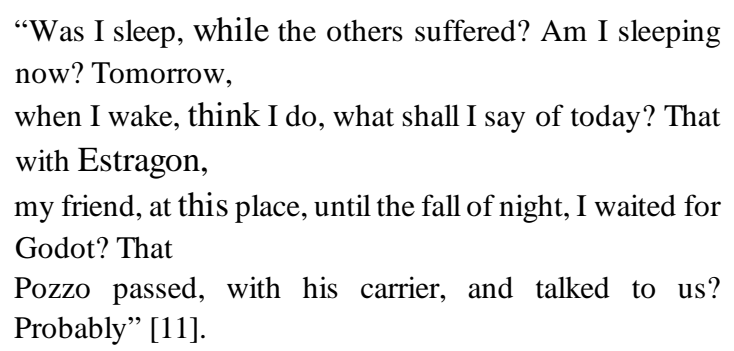

In this passage, it's not just the past but also the future that gets dragged into Vladimir's questioning awareness of the past. This is a small and early example of what later becomes an important tendency in Beckett to emerge all the tenses into a continuous present [12].

Uncertainty of identification is on all sides: Estragon's boots were black when he threw them away but they now brown. Are you sure they were black? he is asked. "Well, they were a kind of grey." "And these are brown" queries Vladimir". Well they are a kind of green," comments Estragon [13].

Estragon and Vladimir found their expectations of a meeting confounded and their sense of certainty in their environment was disconcertingly undermined. The circular play structure permits simple variations on their situation in A ii, while Estragon and Vladimir try to fill the silence and either to energize or to leave their minimal set. The second pair offered some diversion; Pozzo intended to sell his roped slave Lucky. However; when they came back in A ii Pozzo had gone 'blind' led and steered by slave 'Lucky' who had gone ‘dumb'. Thus, their positions were revered in a striking image of the reversibility of power which nevertheless suggested residual interdependence (p.49) [3].

\section{ELEMENTS OF UNIVERSALITY}

There are some elements should be existed in any literary work to be universal. First, the poetic form which basically depends on a special language. Second, the universal or non-determined theme. Third, the influence of the play which 
is shown in others' works:

\section{POETIC Form}

The theatre of absurd depends deeply on dreams and delusions. Exactly as poetic theatre but differs in refusing consciously poetic dialogue, and this theatre can transfer only what a poet has of deep obsessions about human conditions and his vision of the world. So, the Theatre of Absurd tends towards the lyrical mode. Just as a poem, which is sometimes a pattern of unfolding metaphors, images and similes. The absurdist play uses concretized poetic images which gradually unfold and revealing their deeper meaning. Besides, the main means of conveying significance and effect in the absurdist play is an image and metaphor [14].

Not all the plays of the "Absurdist Theatre" are dreams like but the poetic image in most of them is the a focus of interest. Most of the conventional plays were primarily written to tell a story or clarify an intellectual dilemma, and this seen as a discursive or narrative form of communications. The plays belong to the Theatre of the Absurd are mainly intended to transfer a poetic image or a sophisticated pattern of poetic images.

Depending on this hint, the play gained most of its universality because of this poetic feature. Poetry is unlike narrative has no borderlines and is not specialized in one specific nation or culture, it touches deeply the relative stable instincts of human beings throughout the ages and all over the world. Whereas, narrative is concerned with minds which differ from time to time and from a place to another because minds change and convert in accordance with the variation of the nature of man through different circumstances which lift its impact on the minds. There is another feature belongs to the nature of Theatre of Absurd that is the impact on the audience was not merely to entertain, but to put the audience through the same experience as the characters: to wait, to try to find meaning and purpose in life, to give substance to our existence. Esslin explains actively how introspectively poetic playwrights such as Beckett tends to neglect the 'realities' of social circumstances and their documentation in favour of an inner truth. Their plays are dreams rather than photographs of the external world, but these dreams are as real to them and to the audience as the external realities are to the Brechtians [15].

\section{THE UnIVERSAL THEME}

'Theme' traditionally means a frequent element of subject matter, but the modern insistence on simultaneous reference to form and content emphasizes the formal dimension of the term The 'theme' is always a subject, but a subject is not always a theme: a theme is not usually thought of as an occasion of a work of art, but rather a branch of the subject which is indirectly expressed through the frequency of certain images, events or symbols. It could be the main idea or message about life that the author wants to convey to the readers. The word 'wants' means it is not necessarily that the message which the author tries to convey to a reader is still the same as the author wants or different readers should understand it as he wants. In order to undergo any confusion, some critics try to define or explain 'theme' in very short sentences: the story's ideas, author's attitude towards those ideas, author's "statement" about these ideas or the attitude of the reader. Generally, 'Theme' should be expressed as a complete sentence: an idea expressed by a single word or a phrase is usually a motif. The 'theme' of a work is not a summary of its plot, on the contrary, unlike plot which deals with the action of a work, theme concerns itself with a work's message or contains the general idea of a work [16].

'Theme' could be universal when it transcends race, gender, sexual preference, and creed. Common themes mostly explore historically common or cross-culturally recognizable ideas, such as ethical questions, and are usually implied rather than stated explicitly. Literary and cultural scholars in England and other countries took a more historically informed and politically sensitive approach to the relationship of literature to society after World War II. The writers such as Raymond Williams, cultural historians such as E.P. Thompson, Neo humanists such as F. R. Leavis, and cultural analysts such as Richard Hoggart studied literature in its real-world settings and attended both to its social effects and to its ethical and moral meanings. They contended that literature was about life, not universal spiritual truths that avoided the specifics of life. [17].

At the same time it is not realized that every 'theme' could be universal even though it is popular in many countries or different societies. Charles Larson depicts very significant anecdote from which we could understand additional meanings about universal themes. He insists that the African novel does not work like western one, because in western literary sense, love as a 'theme' is simply missing and sex, seduction and romance are not involved in African fiction. "I was more than surprised to learn that Africans, traditionally at least, do not kiss; to learn that what I thought was ' natural' in one society and is not natural at all, but learned, that is, cultural. Not all peoples kiss” [18].

Beside the theme inserted in the title 'waiting', there are other themes in 'Waiting for Godot', which captured a critical attention. These are: triviality and boredom of human life, the prevalence of suffering, the theme of ignorance, the theme of economic and intellectual exploitation and the theme of meaninglessness of space, time and identity and then the theme of 'Nothing to be Done' which means nihilism of life.

The play gives an insight into the universality of the human condition, and does so without preaching or pretending to have the "answer". No doubt, any of these themes could be found anywhere at any time. One of the most important themes is the theme of a savior which is a designation belongs to God or to Jesus Christ in the Christian world and Al-Muntadher or the redeemer in the Islamic world, as the savior for those, who have been waiting for many centuries. So the idea of a savior or redeemer is present in the two major religions and it maintains its universality as people believe that the savior could determinate their suffering, while his doing nothing might be a 
cynical reflection concerning man's forlorn state.

In 1987, after the American congressional hearings about the so-called Iran-Contra scandal, the New York Times columnist, Tom Wicker, wrote a piece titled 'Godot Isn't Coming' to warn the field of democratic presidential hopefuls that the ideal candidate is unlikely to appear at the last moment One more important evidence of the universality of Godot comes from the world of spoof and parody. The Yugoslavian writer, Miodrag Bulatovic, achieved some notoriety in 1966 with Godo je dosao (Godot Has Arrived), a play written in Serbo-Croatian, translated into German and French, and performed in cities around Germany and in Sweden. It has been performed, in celebrated productions at many of the major theatres of the world: at the Odeon in Paris in 1961; at London Royal Court in1964, in Beckett's own production at the Schiller Theater in Berlin in 1975, versions of which later toured in England, America, and Australia; at the National Theatre in London in 1987, and at Lincoln Center in New York in 1988. In cartoons, newspapers, magazines, night clubs, and television shows, the words and images of Godot are now as common and recognizable as images from Picasso, Kafka, T. S. Eliot, Giacometti or Joyce [19].

Also the famous Arabian poet Nezar Qabbani employed the title of the play in one of the most important and widespread poem in modern Arabic literature, the title of the poem is 'بانتظار غودو' which is the Arabic translation of 'Waiting for Godot'. He employed the theme of waiting to describe and criticize the contemporary Arabic circumstances, where the Arabic characters in Qabbani's poem are duplicates of the characters of Beckett's play facing the same dilemmas.

\section{The Universality of the Play}

The unusual universality of the discourse that has formed around Beckett, lies precisely in the fact that it permits an affirmation of the values of literature and culture themselves. At the same time, an assertion of the power of the criticism as the privileged mediator of that culture. The necessity of this affirmation is particularly great at time when criticism and its institutions in Britain and USA have been increasingly drawn to the centers of state-based power while being simultaneously stripped of their cultural and ideological effectiveness. Beckett's works suggest that the dangerous openness of repetition and his practice as a director put some parts of the Beckettian myth under strain. The cultural claim underlies much of Beckett criticism, though it doesn't often come to light in quite so unguarded a way as this [20].

The names of the actors in the play 'Waiting for Godot' are taken from different nations, therefore, this plays a part in the universality of the play: Estragon is French, Vladimir is Russian, Pozzo is Italian, Lucky is English. There must be some design in assigning names to the characters drawn from different nationalities. Obviously, it has nothing to do with characteristics of these nations. If the names are not controversial, it means that the readers are required to consider the play, not as an isolated piece of inaction in a corner of
France, Ireland or Russia but as a universal state that the world condition in which all humanity is involved.

Lucky reveals the depreciation of the Christian devotion with the constant oblique references to "Cunard";Sir Samuel Cunard, who found the line of Cunard steam ships in the midnineteenth century. The ships that did well in the Crimean War (1853-1856), which were broken down because the conflict among Russia, France, and Turkey over Holy Places in Jerusalem. This reference is coincided with an event in early 1948, the year that 'Waiting for Godot' was written, Israel became a nation containing many of the same Holy Places. The very next day, the Arabs composed partially of Christians, attacked the Israelis and stormed East Jerusalem and the Holy Places. Men were murdering each other to have the city where one religion of peace and sharing began [21].

It is pointless to look for logical and universal message behind Beckett's work. He presents an experience not an argument, truth not statement and each spectator or listener must respond in his own terms. Thus, one critic described the performance of Waitng for Godot in the following words : 'It was an experience, symbolic in order to avoid all personal error by an author, who expects each member of his audience to draw his own conclusions make his own errors'. Another critic described it as 'a statement in dramatic terms of the wretchedness of man without God', while another one saw it as 'a general expression of the futility of human existence when man pins his hope on a force outside himself'. Both interpretations, the first by a devout Roman Catholic and the other by a firm existentialist, are equally valid and equally irrelevant since Beckett is not concerned with any religious or philosophical beliefs. He created a new kind of play and in doing so, he greatly enlarges the scope of theatre [22].

\section{CONCLUSION}

It could be said that all cultural differences disappear as soon as the receiver is acquainted with such a mortal literary work. This work reveals the scope of harmony among human societies, since it deals with catastrophes and troubles that almost societies face. So the play 'Waiting for Godot' defeats all the social and cultural differences and conflicts to show the human nature.

Waiting for Godot is a non-traditional, passive and a play of inaction. These characteristics play a major role in its universality. Besides, there are certain elements enabled the play to be universal, one of them that it does not have the traditional rules of plays, in other words, it jumped out of the traditional circle of play writing. It is a reflection of the catastrophic human condition in the post-wars period and the instability of the way the characters think is a clear proof of the human condition.

The universality of the play comes from its main theme, which is 'waiting' because waiting is a universal phenomenon and we practice this phenomenon in everyday life. Besides, the names of the characters were taken from several nations, 
moreover, the play does not address a particular nation but it addresses the nations that suffered in the second world war. Thus, the play in conformity of the said elements is universal and it is treated as a mark of distinction in English literature. It is being taught in all universities around the world and still performed in festivals in many countries as a proof of human identity dispersion.

\section{REFERENCES}

[1] J. Kalb, Beckett in Performance, Cambridge: Cambridge University Press, 1989, pp. 3-4.

[2] M. Esslin, The Theater the Absurd, London: Eyre \&Spottiswoode, 1966, p. 40.

[3] R. Ian, English Drama Since 1940, London: Longman, 2003, p. 47.

[4] How does Samuel Beckett's waiting for Godot reflect on the existentialist view of human reality? (Jan. 2015). eNotes, 28. [Online]. Available: https://www.enotes.com/homework-help/how-does-waiting-godot-reflec t-existentialism-view-473975

[5] B. H. Matthew, Rethinking the Politics of Absurdity: Albert Camus, Post-modernity, and the Survival of Innocence, London: Routledge, Taylor \& Francis Group, 2014, p. 29.

[6] S. Beckett, Waiting for Godot, New York: Grove Weidenfeld, 1957.

[7] E. Bornstein, "Rituals without final acts," in The Limits of Meaning: Case Studies in the Anthropology of Christianity, E. Matthew \& Matt, Tomlinson, Eds., Oxford: Berghahn Books, 2006, pp. 88-89.

[8] M. Esslin, "Godot and his children: The theatre of samuel beckett and harold pinter," in Modern British Dramatist: A Collection of Critical Essays, R. Brown, Ed., New Delhi: Prentice Hall of India Private Limited, 1980, p. 58.

[9] S. Gupta, AStudy of Waiting for Godot, New Delhi: Prakash book, 1985, p. 52.

[10] G. Whitfield, An Introduction to Drama', Oxford: Oxford University Press, 1963, pp. 190-191.

[11] S. Beckett, Waiting for Godot: A Tragicomedy in Two Acts, London: Alabaster Passmore\& Sons Ltd, 1972.
[12] R. Hayman, Contemporary Playwrights, Samuel Beckett, London: Heinemann Educational Books Ltd, 1968, p. 17.

[13] A. Uhlmann, Samuel Beckett in Context, Cambridge: Cambridge University Press, 1959, pp. 48-50.

[14] M. Esslin, An Anatomy of Drama Farrar, Straus and Giroux, 1977, p. 66

[15] M. Esslin, Introduction to Absurd Drama, Penguin Books, 1965, pp. 116-117.

[16] P. Childs and R. Fowler, The Rutledge Dictionary of Literary Terms, New York: Rutledge, 2006, p. 239.

[17] Y. Hakutani, Cross-Cultural Visions in African American Modernism, Ohio State University, 2006, pp. 3-4.

[18] C. R. Larson, "The heroic ethnocentrism: The idea of universality in literature,” American Scholars, vol. 42, no. 3, p. 78, 1973.

[19] L. Graver, The American Congressional Hearing, Cambridge: Cambridge University Press, 2004, pp. 82-86.

[20] S. Connor, Samuel Beckett: Repetition, Theory and Text, Oxford: Basil Blackwell Ltd., 1980, pp. 198-199.

[21] G. Tigani, The Parallel between Christ and Lucky, godot_greg, Yale University, pp. 1-4.

[22] D. Peter, Vladimir's Carrot: Modern Drama and the Modern Imagination, Chicago: University of Chicago Press, 1987, p. 18.

Khalid J. Alogaili was born in Baghdad, Iraq in 1975. He got his bachelor degree in English language from Baghdad University in 2006. He completed his MA degree in English literature at Pune University, India in 2010. He is a member in TESOL Iraq association and in Iraqi translator's association. Currently, he is a lecturer in the Department of English, Faculty of Arts, University of Kufa.

Ali G. Khalaf was born in Basrah, Iraq. He completed his undergraduate degree in Arabic language in College of Arts University of Basrah and a bachelor degree in English language in University of Kufa. He obtained his master degree in modern Arabic literature from Basrah University and $\mathrm{PhD}$ from University of Baghdad. His published books: Employing Arabic inherited tale in Arabic contemporary novel, Place in Abdulrahman Muneef's novels and Poetic of Arabic narration. He is a member of editorial board of College of Arts journal, a member in the Union of Iraqi Writers and in Iraqi translators' association. Currently, he is a professor in University of Kufa. 